\title{
FRONTEIRAS SOCIAIS E SIMBÓLICAS EM UM CLUBE DE ELITE*
}

\author{
Karen Teresa Marcolino Polaz
}

Universidade Estadual de Campinas (Unicamp), Campinas - SP, Brasil. E-mail: karenpolaz@gmail.com

\section{Ana Maria Fonseca de Almeida}

Universidade Estadual de Campinas (Unicamp), Campinas - SP, Brasil. E-mail: aalmeida@unicamp.br

DOI: $10.1590 / 339804 / 2018$

\section{Introdução}

Embora a desigualdade social brasileira, classificada como uma das maiores do mundo, venha sendo estudada há bastante tempo (Langoni, 1973; Tolipan e Tinelli, 1973; Barros, Henriques e Mendonça, 2000; Soares, 2010; Medeiros, Galvão e Nazareno, 2015), ainda estamos longe de compreender grande parte dos processos que a constroem e conservam. Sua persistência no tempo, desafiando políticas públicas de vários tipos (Blofield, 2011; Neri, 2011; Medeiros e Souza, 2016), indica a necessidade de buscarmos entender também as dinâmicas culturais que a tornam possível.

* As autoras agradecem à Fapesp e ao CNPq pelo apoio para a realização desta pesquisa.

Artigo recebido em 20/02/2016

Aprovado em 18/12/2017
Quando se trata de compreender processos que levam à ocupação de posições mais ou menos privilegiadas, à produção e reprodução de diferenças entre grupos sociais e mesmo à legitimação da desigualdade, o argumento cultural pode ser desenvolvido, como propóe Maria Charles (2008), abordando diferentes dimensóes, tais como: traços de personalidade, atitudes ou valores internalizados, repertórios institucionalizados de ação e estruturas cognitivas que acompanham clivagens sociais nos processos de diferenciação, separação e agrupamento.

Essa linha de análise não é, evidentemente, uma novidade na discussáo sobre a desigualdade brasileira. Ela constitui uma longa tradição analíti$\mathrm{ca}$, reunindo trabalhos que oferecem contribuiçóes substantivas para a questão, mesmo quando o termo desigualdade não é explicitamente mencionado (Freyre, [1933] 1995, [1936] 2003; Carvalho, [1980] 2012; Souza, 2006). 
Um dos limites dessa tradição analítica encontra-se, no entanto, como argumenta Omar Lizardo (2006), na tendência a associar amplas configuraçóes culturais à estrutura social tratada de forma genérica ou mesmo generalizante, sem que mediaçóes entre uma dimensão e outra sejam especificadas apropriadamente. Tentativas de pensar a cultura com base em práticas passíveis de ser examinadas no espaço concreto das relaçóes sociais podem ser uma maneira de resolver esse problema (Lizardo, 2006), como mostra uma série de estudos publicados no Brasil a partir dos anos 2000, que se dedicaram a investigar as percepçóes que diferentes fraçóes das elites têm sobre a pobreza, na tentativa de explorar os vínculos causais entre cultura e desigualdade (Reis, 2000, 2004, 2005, 2011; Reis e Moore, 2005; Scalon, 2007, Silva e López, 2015).

Estudos como esses são relevantes para o debate sobre a resiliência da desigualdade, porque ampliam a nossa compreensão quanto à maneira como aqueles que dispóem de maior controle sobre os recursos necessários para enfrentar a pobreza a compreendem, a explicam e, eventualmente, formulam soluçóes para enfrentá-la. Essa literatura mostra que as elites brasileiras tendem a enxergar a pobreza como um problema social importante (Reis e Moore, 2005), a mobilizar razóes estruturais históricas e políticas - para explicá-la, em vez de pensá-la como efeito de maior investimento no trabalho - mérito - ou mesmo "sorte" (Silva e López, 2015) e a atribuir ao Estado a responsabilidade por implementar medidas para controlá-la.

No entanto, a visão da pobreza que emerge desses estudos é sobretudo abstrata, desvinculada da experiência concreta dos interrogados, como notam alguns dos próprios autores (Reis e Moore, 2005). Aprendemos, com esses estudos, o que os interrogados pensam sobre a pobreza, mas temos poucos elementos para saber o que pensam sobre os pobres ou sobre como o que pensam sobre a pobreza interfere no modo como formulam a distância social. ${ }^{1}$ Isso não é exatamente surpreendente, considerando que a própria desigualdade brasileira faz com que a pobreza seja, de fato, algo bastante distante da experiência cotidiana dos grupos mais privilegiados, que vivem em mundos afastados daqueles habitados pelos pobres, como argumenta
Merike Blofield (2011) e como documentam Ana Maria F. Almeida e colaboradores (2010).

Essas são lacunas que este artigo buscará preencher, amparado nos resultados de uma pesquisa que mapeou as categorias que as elites econômicas de uma cidade de porte médio do interior de São Paulo mobilizam quando pensam sobre o que os diferencia daqueles que consideram como o outro, e, estudou os processos de separação e agrupamento em que se engajam.

Inspiradas pelo esforço contemporâneo de marcar a "convergência entre sistemas simbólicos e formas indiretas de poder" (Lamont e Molnár, 2002), exploramos o trabalho de diferenciação em que os indivíduos investem, ao mobilizar esses sistemas de classificação, como um trabalho de construção de fronteiras, o que implica sublinhar a importância do contato e da comunicaçáo entre grupos - separados por princípios de divisão de diferentes tipos - para os processos de construção identitária (Barth, 1969).

Para Fredrik Barth e, depois, Michèle Lamont (1992, 2000b), e também para Charles Tilly (2006), entre outros, a noção de fronteira permite conceituar a interação entre indivíduos e grupos quando, separados por divisóes de diferentes tipos, como classe social e etnia, se pensam mutuamente como sendo o outro. ${ }^{2}$ Assim, a constituição de fronteiras seria um dispositivo regulatório, que permite uns se diferenciarem dos outros. Ela estaria em contínua construção nas interações que têm lugar em diferentes esferas da vida social, aproximando-se dos processos de fechamento social examinados por Max Weber (1999). Nessa perspectiva, a operação de definir quem somos faria parte de um processo, contínuo e socialmente situado, de determinação de quem é o outro e, por conseguinte, de quem não somos.

Nessa literatura, fronteiras são pensadas como dotadas de um caráter bidimensional, ao mesmo tempo categórico e comportamental (Wimmer, 2008). A primeira dimensão se refere às práticas de classificação, enquanto a segunda está relacionada às interaçóes cotidianas ao longo das quais os indivíduos se agrupam ou se separam. A primeira dimensão diz respeito, mais precisamente, às operaçooes cognitivas de separação entre "nós" e "eles", já a segunda refere-se à orientação da ação, às ope- 
raçóes de definição do tipo de relação que se pode estabelecer com os indivíduos em função do seu pertencimento ao grupo do "nós" ou ao grupo dos "eles". A primeira dimensão aproxima-se do que Michèle Lamont e Virág Molnár (2002) tratam como fronteira simbólica e a segunda aproxima-se do que esses autores denominam fronteira social.

Nesse sentido, uma fronteira social se estabelece apenas quando os dois esquemas coincidem, isto é, quando maneiras de ver o mundo correspondem a modos de ação no mundo (Wimmer, 2008). Estudar fronteiras sociais e simbólicas, tal como proposto na pesquisa que deu origem a este artigo, corresponde, portanto, a um esforço para compreender os mapas mentais, os sistemas de classificação que indivíduos mobilizam quando pensam sobre si mesmos em relação aos outros, e vice-versa, e para registrar o modo como os indivíduos definem distâncias quanto a certas categorias de pessoas, o que é revelado, por exemplo, em suas escolhas matrimoniais ou nas características das redes de sociabilidade a que se articulam (Lamont e Molnár, 2002; Pachucki, 2007; Saint Martin e Gheorghiu, 2010).

A pesquisa empírica teve lugar nas dependências de um clube privado, socialmente seletivo, aqui denominado "Clube Equestre", localizado em uma cidade de porte médio do interior paulista. A unidade de análise definida foi "a família", na medida em que o clube representa, para o grupo aqui observado, uma espécie de continuidade da casa, concentrando grande número das atividades de que todos os membros da família participam. O clube é especialmente importante para as crianças e adolescentes, que, durante a semana, passam ali boa parte do dia, envolvidos em atividades diversas. Com isso, foi possível incluir, na análise, esses membros das famílias, tantas vezes deixados de lado nos estudos sobre os grupos dominantes.

Esta pesquisa abrangeu observaçóes e entrevistas. As observações permitiram explorar comportamentos e discursos produzidos em situaçóes de descontração, em momentos de comemoraçáo e alegria, mas também de raiva, frustração e/ou dor. As entrevistas, por sua vez, deram acesso às explicaçóes e justificativas dos indivíduos interrogados sobre sua maneira de pensar e de agir, em suma, sobre o significado por eles atribuídos a comportamentos e decisóes observados ou relatados. Foram entrevistados mães, pais, filhos, funcionários do clube e das famílias, procurando-se documentar os modos de tratar, de se dirigir a, de se referir a e, não menos importante, de pensar sobre si próprios e sobre os diferentes grupos de indivíduos com os quais convivem no clube. Entre as famílias frequentadoras do Clube Equestre, o foco da pesquisa foi colocado sobre aquelas cujas filhas e filhos praticavam hipismo, esporte que deu origem ao clube e que continua definindo seu lugar social na cidade. ${ }^{3} \mathrm{~A}$ associação entre observaçóes e entrevistas se revelou uma estratégia valiosa para escapar do tratamento excessivamente individualista e distante da experiência vivida de que são acusados alguns estudos que se dedicam apenas ao exame das percepçóes autodeclaradas pelos entrevistados (Jerolmack e Khan, 2014).

Ao longo dos dezoito meses de pesquisa de campo, foram produzidas duas centenas de páginas do diário de campo, escritas no editor de textos MS-Word, e dezenas de horas de entrevistas gravadas e depois transcritas. A exploração desse material se revelou uma tarefa complexa e desafiadora. A codificação do material foi realizada de forma indutiva, pela identificação de padróes nos discursos e nos comportamentos. $\mathrm{Na}$ apresentação dos resultados a seguir, selecionamos as frases e expressóes exaustivamente repetidas em campo, bem como os conteúdos mais frequentes, sobre os quais construímos a análise. É importante notar, portanto, que a discussão proposta aqui não pretende esgotar todas as dimensóes da experiência vivenciada pelos indivíduos que frequentam esse clube. Diferente disso, ela privilegia uma dimensão dessas experiências, mais precisamente a que diz respeito ao modo como percebem aqueles com quem dividem esse espaço e como organizam suas relaçóes com essas pessoas.

\section{O clube: espaço segregado e segregador}

A fim de compreender o espaço onde têm lugar as interaçóes por meio das quais se desenvolvem processos sociais de separação e diferenciação, examinados neste artigo, adiantamos, nesta seção, alguns elementos que permitem compreender melhor a posição social das famílias que frequentam 
o clube, assim como o significado que as mesmas atribuem à sua situação de associadas. Sublinhamos, em particular, a posição que ocupam na hierarquia social da cidade.

$\mathrm{Na}$ cidade onde o clube se situa, há parques e clubes públicos, com pista de corrida, quadras e piscinas. Nos bairros populares e de classe média baixa, é possível encontrar jovens jogando bola em quadras públicas nos finais de tarde durante a semana e nas manhãs e tardes dos finais de semana. Nos bairros ricos e de classe média alta, as quadras públicas, quando existem, permanecem, em geral, vazias. Os clubes privados são o destino preferido dos mais privilegiados. O Clube Equestre ocupa um lugar especialmente valorizado em meio a um amplo conjunto de clubes, em parte por o Equestre concentrar grande parcela das famílias mais tradicionais e influentes da cidade. Os sobrenomes de vereadores e prefeitos da cidade, antigos ou recentes, que se reproduzem também em nomes de ruas, avenidas, praças, monumentos, edifícios e escolas, remetem aos sobrenomes dos que dirigiram o clube desde a sua fundação até os dias de hoje, mostrando que a afiliação a clubes está longe de ser algo aleatório, mas se inscreve no rol durável e complexo de práticas que definem uma posição social (Bond, 2012).

A maioria das famílias que frequenta o Clube Equestre hoje compartilha um modo de vida muito distante do modo de vida dos grupos menos privilegiados. Essa distância está inscrita, por exemplo, em suas moradias, em geral situadas nos "enclaves fortificados" ou "guetos voluntários", estudados por Teresa Pires do Rio Caldeira (2000) e Michel Pinçon e Monique Pinçon-Charlot (2007). São apartamentos confortáveis localizados nos endereços mais valorizados da cidade ou casas amplas em condomínios residenciais, bastante homogêneos em termos sociais - separados da cidade por "muros e tecnologia de segurança” (Caldeira, 2000, p. 171) e em seu modo de vida. Quando vão às compras, essas famílias dão preferência a lojas que se encontram em shopping centers, igualmente separados do ambiente mais heterogêneo da rua, localizados nos bairros mais nobres da cidade, reforçando a homogeneidade social de sua clientela.

Essa espécie de clausura se afirma também, em outras esferas. Quando precisam de médicos, esses membros dos grupos mais privilegiados vão a consultórios e hospitais cujo acesso depende do desembolso de tarifas altas ou da adesão aos planos de saúde privados mais onerosos. Quando se deslocam pela cidade, utilizam transporte privado, e, se há crianças e adolescentes na família, eles frequentam alguma das poucas escolas privadas prestigiosas da cidade; além disso, são organizações privadas, clubes ou empresas que oferecem, mediante o pagamento de mensalidades elevadas, as atividades esportivas, acadêmicas e artísticas das quais participam. ${ }^{4}$

Além de habitarem bairros e condomínios valorizados, de manterem os filhos e filhas em escolas que cobram altas mensalidades, de frequentarem clubes socialmente seletivos, essas famílias costumam viajar para destinos caros no Brasil e/ ou no estrangeiro, dispóem de automóveis que se destacam pelo tamanho e/ou pelo prestígio do fabricante, exibem os modelos mais recentes de aparelhos eletrônicos, como telefones celulares das marcas mais valorizadas - Apple, por exemplo -, e se vestem com roupas e acessórios de marcas que só podem ser comprados nas lojas dos shopping centers mais exclusivos da cidade ou em outros países. As posses e gastos dessas famílias podem ser vistos como "marcadores públicos de categorias sociais", no sentido proposto por Mary Douglas e Baron Isherwood (2004), permitindo que os indivíduos se reconheçam como membros de um mesmo grupo, ao mesmo tempo que marcam sua diferença com relação aos que podem considerar como o outro.

A própria prática do hipismo, privilegiada pela maioria das famílias ouvidas na pesquisa, pode ser incluída entre esses marcadores, já que os esportes equestres apresentam uma longa história de associação, ainda que não exclusiva (Melo, 1998; Adelman e Moraes, 2008), com as classes altas (Fletcher e Dashper, 2013). Uma das modalidades clássicas do hipismo, que consiste no salto sobre obstáculos em um percurso previamente definido e no menor tempo possível, é um dos seus ramos mais associados às elites, em parte por sua vinculação histórica com a nobreza guerreira, mas também pelos altos investimentos financeiros que requer. Para a compra de um cavalo de salto, as famílias do clube chegam a gastar, dependendo das características do animal, entre 5 mil reais em um animal já mais velho e mais de de- 
zenas de milhares de euros ou dólares em um animal jovem, de origem selecionada e criado ou adestrado por renomados criadores brasileiros ou estrangeiros. O gasto varia em função de suas posses e do investimento que pretendem fazer na preparação dos filhos, que vai da prática do hipismo à participação em tantas provas quantas possíveis. $\mathrm{O}$ esporte exige, além disso, elevados gastos regulares com a manutenção do animal - estábulo, alimentação, veterinário, tratadores, vacinas, remédios, eventuais cirurgias etc. bem como com seu deslocamento para as competiçóes, além de despesas para prover o cavaleiro ou a amazona dos trajes, calçados e acessórios apropriados, também de custo alto.

Nas conversas e entrevistas que tiveram lugar no clube, quando os sócios adultos falavam em "manter a família”, por exemplo, estavam referindo-se a poder pagar por todo esse conjunto de bens e arcar com os gastos dele decorrentes. No contexto dessa cidade, isso permite localizar seus proprietários nas camadas mais privilegiadas da hierarquia social.

De fato, a maioria dos sócios exerce profissóes de elevada remuneração. Alguns são altos executivos de grandes empresas nacionais e multinacionais, outros sáo proprietários de empresas grandes e médias do setor têxtil, de serviços, da construção civil, de transportes. Outros, ainda, são sócios de escritórios de advocacia ou proprietários de clínicas e hospitais importantes da cidade. Identifica-se, ainda, um grupo de executivos de médio escalão, assim como profissionais liberais e professores universitários. Vários desses últimos são associados ao clube devido ao pertencimento, por nascimento ou casamento, a famílias proprietárias da região. Trata-se, não obstante, de famílias que se dizem em condição econômica "melhor" do que a que experimentaram na infância ou da que seus pais e/ou avós tiveram.

Nesse quadro, a frequência regular ao clube é apenas uma das dimensóes em que se afirma o desejo de "estar entre si" (Pinçon e Pinçon-Charlot, 2007). Sua importância para os membros dos grupos mais privilegiados, especialmente no que diz respeito a estabelecer e manter redes, tem sido indicada com frequência na literatura sobre as elites (Baltzell, 1964; Domhoff, 1971, 1975; Ostrander, 1984). Edward Digby Baltzell (1964, p. 364), por exemplo, afirma que os clubes privados "estão no núcleo da organi- zação social que dá acesso a poder e autoridade", no caso dos grupos estudados por ele.

Para além dos benefícios bastante concretos, que derivam da frequência regular ao clube, já identificados nessa literatura, o fato de que os indivíduos desses grupos consigam se separar dos outros na sua vida cotidiana de forma tão eficaz, construindo ambientes fortificados cuja frequência controlam, tem consequências importantes sobre a maneira como concebem seu lugar no mundo. Nas situaçôes em que podem construir relaçôes horizontais de amizade e camaradagem, eles se encontram em companhia de indivíduos da mesma camada social. Quando convivem com membros de grupos menos privilegiados, estes estão inevitavelmente em posição subalterna, prestando serviços como empregadas domésticas, babás, jardineiros, motoristas, porteiros, funcionários de lojas, clubes, escolas etc.

O clube pode ser visto, nesse contexto, como um microcosmo onde muitas das tensóes inerentes a esse modo de organização das relaçóes sociais estão presentes. O Clube Equestre oferece condiçóes singulares para captar os dinâmicos processos de construção e transgressão de fronteiras nos quais os membros dos grupos mais privilegiados da cidade se envolvem, já que ali é possível observar a relação que estabelecem tanto com aqueles que estão em situação similar - os demais sócios -, como com aqueles que se encontram em posição subalterna, como babás e motoristas que dão suporte às famílias, e funcionários que garantem o bom funcionamento do clube (jardineiros, limpadores de piscina, encarregados de manutenção, funcionários administrativos, instrutores de esportes, entre outros). Além disso, como se trata de um local frequentado para se dedicar ao lazer, onde as pessoas podem estar ou devem se mostrar mais à vontade, a observação da experiência cotidiana no clube ofereceu oportunidades para contornar as estratégias que esses grupos costumam desenvolver para controlar a situação de entrevista (Pinçon e Pinçon-Charlot, 1997; Almeida, Moschkovich e Polaz, 2012).

Como em qualquer clube privado da cidade, a frequência regular ao Equestre só pode dar-se mediante a obtenção de um título de sócio. Para aqueles que não o receberam como herança, isso envolve uma operação antes de tudo econômica: 
a compra do título. Como não são criados títulos novos há bastante tempo, tal compra somente pode acontecer se houver oferta por parte dos associados que pretendem desistir de seus títulos, o que raramente acontece. Em fevereiro de 2016, por exemplo, havia apenas seis títulos à venda. A aquisição de um título exigia, na época, o desembolso de 115 mil reais. O valor do título impóe um controle bastante rígido sobre quem está ou não autorizado a pleitear a associação. No entanto, como veremos mais à frente, o custo subjetivo da venda é bastante alto, o que faz do título um bem de pouca liquidez, cujo valor não pode ser totalmente definido pelo cálculo monetário.

Além da dimensão econômica, outros dispositivos institucionalizados contribuem para o controle da composiçáo do conjunto de sócios. O próprio processo de associação pode ser considerado um exemplo particularmente instrutivo da maneira como repertórios classificatórios podem ser acionados em processos de fechamento social, no sentido weberiano do termo (Weber, 1999). Como nos explicou uma das mães, os interessados em comprar um título não podem apresentar-se diretamente ao clube como sócios potenciais, mas devem ser "indicados" à diretoria por dois sócios proprietários. Cada demanda de associação é analisada por uma comissão encarregada de verificar a adequação do candidato ou candidata ao clube. $\mathrm{O}$ esforço dispendido na implementação de procedimentos para definir quem merece ou não ser sócio revela a energia social investida na separação do grupo de sócios daqueles que consideram como outro. Essa é também, uma das estratégias pelas quais se garante a homogeneidade social do clube e sua continuidade ao longo do tempo.

A submissão a todo esse processo gera benefícios para além do usufruto de um espaço de lazer, já que o pertencimento ao grupo restrito daqueles que podem se definir como sócios funciona como um marcador de status, cuja importância é sublinhada frequentemente por eles mesmos. A sócia Eliza (40 anos, formada em arquitetura, mãe de dois meninos, de 14 e 10 anos), explica a particularidade desse clube em relação a outro localizado na cidade, em um bairro próximo: "Antigamente todo mundo que era sócio do Equestre era sócio do [outro clube], era todo mundo igual, e era gos- toso... Mas [o outro clube] decaiu muito, muito, muito [ao ampliar o acesso a novos membros]". As próprias crianças parecem compartilhar dessa percepção. Uma delas, certa vez, perguntou a uma de nós: "Ah, não vai dizer que sua vida não melhorou depois que você passou a vir para o Equestre?”. Em outra oportunidade, quando essa mesma pesquisadora mencionou que não conhecia o Equestre antes de iniciar a pesquisa, outra criança retorquiu: "Que absurdo!”, e completou afirmando que sua interlocutora era "uma pessoa sem cultura”.

A sinalização de alto status proporcionada pela posse do título do clube fica visível até mesmo na relutância experimentada por algumas famílias em vender o título, mesmo quando passam por períodos de dificuldade financeira. Mariana (25 anos, formada em direito) explica que "vender o título do Equestre é aceitar que você quebrou. E ninguém aceita [risos]". A posse do título funciona, assim, como um mecanismo de definiçáo de uma autoimagem particular, amparada pela confiança que deriva da convicção de que se pertence a um lugar "exclusivo" e "superior".

Compreensivelmente, isso resulta em intenso trabalho de controle sobre a frequência ao clube, no qual se engajam não apenas os seguranças, mas também os próprios sócios, dando origem a "denúncias", que, por sua vez, geram medidas da administração para verificar o direito de a pessoa denunciada estar ali. Tais situaçóes são particularmente constantes em relação ao público que frequenta as aulas de equitaçáo, atividade em que, à época da pesquisa, podiam inscrever-se crianças e adolescentes não associados. Dois instrutores de equitação entrevistados se referiram a episódios de controle sobre o que é considerado, no clube, excessos dos não sócios. Em um dos casos, relataram que um de seus alunos não sócio costumava, depois da aula, "sair para curtir o clube", até o dia em que alguns sócios solicitaram à administração medidas para "intimidar o garoto", a fim de restringir suas atividades apenas às aulas de equitação.

As crianças e adolescentes da escola de equitação também se engajam em manter o clube fora do alcance de seus colegas que "não têm o título nem pagam mensalidade". Como questionou uma 
indignada Daniela (13 anos), ao perceber que era observada enquanto vigiava um colega não sócio: "Nossos pais ficam pagando para eles virem aqui e usarem de graça?”.

Esse controle não poupa nem aqueles que, embora não sejam sócios, ocupam uma posição social destacada em relação a esse grupo táo privilegiado. Os adolescentes referiram-se, por exemplo, ao caso de uma garota que treinava para competição nas dependências do clube. Embora a família, considerada "riquíssima" por eles, muito conhecida na cidade em virtude dos negócios que mantém na região, não se interessasse em obter um título de sócio, a garota era tão frequentemente "denunciada" por outros sócios que os familiares optaram por comprar o título apenas "para evitar constrangimentos", como explicaram seus colegas de hipismo.

A separação entre sócios e não sócios tem como um de seus mais importantes efeitos ocultar, para os "de fora", as diferenças entre os diversos segmentos da elite local ali representados, inclusive obscurecendo oscilaçóes nas condições materiais que membros desses grupos podem experimentar ao longo da vida. $\mathrm{O}$ intenso trabalho dedicado à separação entre sócios e não sócios sinaliza como se constrói a percepçáo de que todos os ali incluídos pertencem, em igualdade de condições, aos círculos sociais mais privilegiados.

No entanto, a semelhança entre os sócios - expressa por certa uniformidade física, pelo uso de vestimentas parecidas e pela posse dos mesmos gadgets não implica, absolutamente, homogeneidade social. Os sócios se diferenciam entre si no que diz respeito tanto ao poder econômico como aos estilos de vida. Eles pertencem a distintos estratos das classes dominantes, uns mais ou menos estabelecidos que outros, uns mais ou menos dominados que outros. No espaço social hierarquizado do clube, nota-se, em particular, clivagens entre famílias que são sócias há várias gerações versus famílias recém-chegadas ou que "não têm uma história no clube", como explicaram alguns; famílias que gozam de boas condiçôes econômicas versus famílias economicamente decadentes; famílias cuja posição privilegiada remonta há algumas geraçóes versus famílias cuja fortuna é recente. Essas e outras diferenças são negociadas nas interações cotidianas e são reveladas nas apreciações sobre o valor do outro, que encontram um canal particularmente apropriado à sua expressão nas fofocas que se espalham pelo clube diariamente.

\section{Amizades, conflitos e fofocas}

Como em quase todos os tipos de configuração social marcados por relações de interconhecimento, também nesse clube as fofocas são fartamente mobilizadas para delimitar fronteiras e consolidar princípios de classificação, contribuindo para dar substância às diferenças entre o "nós" e "os outros" ,e indicando como os diferentes grupos e indivíduos se colocam e se percebem no mundo (Elias e Scotson, 2000; Lacy, 2007).

Claudia Fonseca (2000), em seu estudo sobre a fofoca em grupos populares, registra que o mexerico pode ser "o instrumento dos que se sentem inferiores e que só podem realçar seu status rebaixando o dos outros". Não necessariamente, como indica o caso de nossos entrevistados e entrevistadas. Ao longo dos vários meses de observação, progressivamente foi possível compreender que as fofocas e maledicências são elementos estruturantes das relaçóes entre os sócios, servindo, aos adultos, para estabelecer e cultivar clivagens no grupo e, no caso dos mais jovens, para exercitar sua capacidade de compreender e mobilizar os sistemas de valores que estão em processo de interiorizar.

Dessa forma, constatamos que nem todos os que se engajam em fofocas o fazem a partir de uma posição inferior. Relativamente discretas, já que reservadas à rede de interconhecimento mais próxima, as fofocas que se disseminam pelo clube parecem ter efeitos essencialmente cognitivos (Brubaker, Loveman e Stamatov, 2004). Sem efeitos mais significativos sobre os indivíduos visados, o mexerico serve, fundamentalmente, para que os fofoqueiros comuniquem uns aos outros os esquemas classificatórios que organizam sua visão de mundo, contribuindo, com isso, para reafirmar a proximidade com o interlocutor e a distância em relação àquele sobre quem se fala, o que não é o mesmo que afirmar sua superioridade.

Assim, fala-se muito sobre os outros no clube; falam, principalmente, mal uns dos outros, isto é, 
criticando e apontando deficiências reais e/ou imaginadas. Da mesma forma como acontece com as práticas de vigilância em relação aos não sócios, falar (mal) dos outros é, também, prerrogativa dos adolescentes. Uma garota de 13 anos, quando perguntada sobre o que mais gostava de fazer no clube, respondeu sem hesitaçáo e com um amplo sorriso no rosto: "o melhor que tem aqui é fofoca. Só tem fofoca. O dia inteiro". Outra garota, de 16 anos, acrescenta que "a vida não tem graça sem falar mal dos outros". Uma instrutora de hipismo chega a dizer que "elas [as crianças] estão mais preocupadas em fazer as fofocas do dia do que em fazer aula [de hipismo]".

Como tanto os sujeitos quanto os objetos das fofocas convivem diariamente no clube, a fofoca póe em circulação, por um mesmo canal, informaçóes e apreciaçóes que contribuem para definir, segundo cada grupo específico, aqueles a quem consideram como "boas pessoas" ou pessoas de "má fama”. As apreciaçóes são, assim, resultado da atribuição de um significado moral aos comportamentos, que se tornam, consequentemente, indicadores do "caráter" da pessoa. Nessa condição, tais apreciaçóes podem ter efeitos muito concretos, mas apenas para o círculo estreito dos fofoqueiros, permitindo observar, como diz Andreas Wimmer (2008), a alimentação cotidiana da "rede de relaçóes que resulta dos atos individuais de conexão e distanciamento". Dela resulta o aprofundamento das amizades, a definição dos parceiros nas atividades de esportes ou de outro tipo em que os sócios se engajam tanto dentro do clube como fora dele. Por outro lado, essas avaliações geram tensão, estimulando antipatias $\mathrm{e}$, às vezes, conflitos. Vale a pena, por isso, explorar o conteúdo classificatório de que são compostas.

Com base nas entrevistas e inúmeras conversas entabuladas ao longo da pesquisa, foi possível registrar, em especial, o caráter moral dos julgamentos enunciados pelos sócios interrogados. Esses julgamentos se manifestam, com frequência particular, na crítica aos indivíduos considerados "improdutivos", que obtêm vantagens e lucros advindos não "da produçáo" nem do "trabalho digno", mas "à custa das pessoas" e, no caso das famílias mais envolvidas com o hipismo, "à custa dos animais". O "esforço" e o "suor" são considerados como etapas necessárias para se atingir o sucesso profissional e/ou financeiro e devem estar evidentes para todos. $\mathrm{Na}$ falta dessas evidências, observa-se que não há "merecimento".

São vistas como desonestas e são mal faladas no clube, por exemplo, aquelas pessoas que, diz a fofo$\mathrm{ca}$, teriam "enriquecido do dia para a noite", como resultado de "negócios de origem obscura", ou que "querem lucrar sem produzir". Assim, numa das entrevistas, Eliza discorreu longamente sobre o caso de um conhecido que havia sido preso por estar envolvido em um esquema de fraudes contra o Estado. Ela comparou o estilo de vida desse homem com o de seu marido, que administra com o irmão uma fábrica de uniformes que herdaram do pai.

Eliza: [Ele] tinha um Hummer, você sabe o que é um Hummer? É aquele carro quadrado, que parece um tanque de guerra. Horrível, por sinal. E falavam que ele dava festas, assim, homéricas, com Clicquot, aquela champagne super cara... e daí, eu falei assim: "O que ele faz?", ela [uma amiga] falou: "Eu não sei, ele faz negócios de oportunidade". Eu falei: "Mas o que são negócios de oportunidade?”. Eu não consigo entender... porque eu consigo entender... assim... o cara é médico, é empresário, industrial, cantor de sertanejo... isso eu ainda entendo, mas o que é você ter "negócios de oportunidade"? [...] É outra coisa que a gente estava falando, eu e o [nome do marido]... a fábrica tem 50 anos, ninguém é rico. Ele acorda 5 h45 da manhã, abre a fábrica... porque, na fábrica, as funcionárias têm que bater o cartão, elas têm que entrar na fábrica antes das $7 \mathrm{~h}$, porque o relógio de ponto bate às $7 \mathrm{~h}$. Então, às $7 \mathrm{~h}$, todas já têm que estar sentadas na máquina. E eles têm um acordo entre eles de que o dono é sempre quem abre, então uma semana é ele e outra é o irmão. Então, é assim, você trabalha que nem um camelo e ninguém é rico. E, de repente, você vê gente assim... [...] você vê gente enriquecendo de um dia para o outro.

As críticas mais virulentas formuladas por Eliza e por outros entrevistados se dirigiam aos sócios que se dedicam ao comércio de cavalos, comprando animais novos e os vendendo, depois de treiná-los, para a prática de hipismo. A obtençáo de lucro pela 
venda de animais, mesmo que sucedida por investimento em treinamento e cuidados prévios, é motivo de forte reprovação. Há toda espécie de suspeita acerca dessa atividade. Fala-se, por exemplo, em animais sendo maltratados, em uso de remédios para mascarar a condição do animal e obter, em consequência, um valor superior ao considerado "correto", entre outros comentários.

Essas críticas dirigem-se, em especial, a transaçóes tipicamente entabuladas no setor informal da economia. Embora tenha sido possível perceber, nas conversas e entrevistas, certo fascínio pelo dinheiro e evidente respeito pelo sucesso econômico, isso coexiste, lado a lado, com a forte recusa ao lucro "direto", "fácil", que é pensado como advindo de uma "origem baixa", "infame", chegando a ser compreendido como um "roubo" cometido por "pessoas ruins" e de "mau caráter".

Entre as mães, crianças e adolescentes diretamente envolvidos com a prática do hipismo, a preocupação com a honestidade é amplamente difundida. Alguns entrevistados criticam, por exemplo, certos instrutores que se utilizariam de meios, segundo eles, nem sempre lícitos, para que seus alunos obtenham melhores resultados nas provas. Mencionam profusos exemplos, embora sempre relatados de modo vago, de episódios em que instrutores teriam dado dicas e orientaçóes aos alunos durante o percurso, prática proibida em regulamento, e indicaram que, em alguns casos, os pais das crianças envolvidas "não tomavam uma atitude" ou "faziam igual". Esses instrutores e, eventualmente, alguns pais, estariam "desvalorizando o treino" e o "esforço pessoal" e, ainda, ensinando às crianças que "vale tudo" para vencer as provas.

Assim, ainda que de maneira pouco elaborada, nota-se que circula, nesse meio, a ideia de que o merecimento deve funcionar como um princípio organizador da desigualdade. Tudo parece se passar como se, para esse grupo, a falta de investimento e de algum sacrifício para se atingir determinadas metas desqualificassem os resultados, mesmo quando bem-sucedidos.

Essa percepção estrutura, inclusive, a relação que os indivíduos estabelecem com seu passado. As histórias das famílias são apresentadas, sem exceção, como histórias de ascensão social ao longo de geraçóes, e todos os adultos entrevistados reafirmam isso com certo tom de orgulho, sublinhando que "não chegaram onde chegaram de repente", "de uma hora para outra". A importância atribuída ao tempo, pensado como um depurador de caráter ou como uma prova que permite medir o valor da pessoa, faz com que a chegada recente e célere à posição dominante cause mal-estar entre os mais estabelecidos.

O caráter difuso e pouco estruturado dessa percepçáo certamente impede concluir que esses indivíduos mobilizem uma ideologia meritocrática, no sentido discutido por Lívia Barbosa (1996). No entanto, nossa pesquisa faz emergir essa associação entre valor da pessoa e merecimento, numa conotação moral bem marcada.

Náo obstante, trata-se de uma ideia atravessada também por contradiçóes, como fica claro na apreciação que os entrevistados fazem do trabalho necessário à criação dos filhos, principalmente quando se trata de julgar a qualidade das mães. Examinamos, em particular, julgamentos expressos exclusivamente por mulheres em situações de entrevista ou conversa, em que procuravam explicar os valores que haviam orientado suas escolhas profissionais ou as relaçóes que estabeleciam com os filhos. Nessas situaçôes, ainda que o trabalho e, sempre associado a ele, o esforço continuem a ser os principais elementos estruturadores do julgamento sobre o valor da pessoa, as outras mães são avaliadas pelas mulheres interrogadas fundamentalmente em função do tempo que passam com os filhos e, em especial, dos "sacrifícios" que devem fazer para garantir tal disponibilidade de tempo. Especialmente valorizados nesse grupo são os sacrifícios que se referem à renúncia à escolarização mais longa ou a carreiras promissoras para dedicar todo o tempo aos filhos. Compreendendo a criança como um projeto maleável, pronta para ser desenvolvida desde que exposta às experiências e aos cuidados corretos (Lareau, 2012; Vincent e Ball 2007; Williams 2006) -, as mães que "não trabalham fora" se mobilizam ativamente para valorizar a função de ser mãe em tempo integral, afirmando que estão "fazendo tudo que podem" em relação à educação dos filhos, o que significa, principalmente, transmitir "bons valores" para que eles se tornem "pessoas de bem". 
Fora do mercado de trabalho, altamente escolarizadas ou, mais raramente, tendo se casado jovens e abandonado ou adiado os planos de finalizar um curso superior, essas mulheres dedicamse integralmente aos filhos. São elas que os levam para a escola e os buscam no final do período escolar, são elas que os acompanham nas inúmeras atividades extracurriculares a que se dedicam, no clube ou fora dele, rotina típica das crianças desse meio social não apenas no Brasil (Vincent e Ball, 2007; Friedman, 2013). Como a escolha das atividades extracurriculares é vista como algo "individual", que decorre das "inclinaçôes", do "gosto" das crianças, não é raro que essas mulheres se vejam atravessando a cidade, várias vezes por dia, para atender às pesadas agendas de cada filho ou filha, que podem envolver aulas de futebol, balé, inglês, artes marciais etc. Como, além disso, são elas que se ocupam de toda a gestão das atividades familiares que abrange definição de cardápios, idas a supermercado e padaria, preparação de lanches, organização de roupas e uniformes, compra de presentes para festas de aniversário, contratação e administração de funcionários etc. -, veem-se obrigadas a empreender uma intrincada organização do tempo, que, ao final, libera pouco ou nenhum espaço para suas agendas pessoais, mesmo fenômeno observado por Lisa Swanson (2009), no seu estudo sobre as chamadas soccer moms nos Estados Unidos. Ao descrever suas rotinas, tem-se a impressão de que essas mães estão, de fato, "a serviço" de suas filhas e filhos, como algumas chegam a afirmar, não raro utilizando a expressão "mãetorista" para se autodescrever. É o que explica Mônica, mãe de um menino de 12 anos e de uma menina de 10 anos:

Mônica: E... eu não consigo falar tempo livre, meu tempo livre é muito curto, porque eu estou sempre com os meus filhos, por exemplo, eu estou com tempo livre aqui agora no Equestre, mas não está livre, porque talvez se ele fosse tempo livre, eu não estaria... eu não estaria aqui no Equestre... [...] Então é difícil, meu tempo livre é curto. Então é aquilo, é tão legal, que você fala: "Ah, eu não trabalho", né? Só que... você acorda... [sou] eu que levo [para a escola] eles não vão de transporte escolar -, eu levo, eu busco, tenho funcionária todos os dias na minha casa, mas [sou] eu que cozinho, sabe, então...

Pesquisadora: Então não é uma babá, é uma empregada doméstica para limpar a casa?

Mônica: É uma empregada doméstica. [Mas] tudo o que está relacionado aos meus filhos [sou] eu que cuido, e eu que acompanho e administro e tal.

Nesse quadro, não é surpreendente constatar que o "trabalho da mãe" possa, de certa forma, ser apreciado segundo os mesmos princípios aplicados ao trabalho do marido, e que a "boa mãe" é aquela que mais se esforça e mais "se desgasta" para prover uma "boa estrutura", que, portanto, "faz por merecer" a boa educação e o sucesso futuro dos filhos. Como explica ainda Mônica:

Eu tenho medo de droga, eu tenho medo... Droga, você quer pior que isso? Mas, por outro lado, quando eu falo que eu tenho medo, é porque eu amo, porque são os meus filhos, embaixo da minha asa. [...] Mas eu falo que eu tenho a minha consciência super tranquila, porque eu anulei a minha vida. A vida da Mônica [se] modificou totalmente. Sabe, é aquilo...estou aqui. Mas vê se você vê mãe aí? Não vê vendo aula, entende? É difícil, estou acompanhando, pego na escola... Na hora que eles entram [no carro, na saída da escola], eu falo "Oi, tudo bem?" Eu olho, eu já sei se está tudo bem, se não está...o cheiro das crianças [mostra], entende? Então, eu tenho a minha consciência super tranquila, super [enfatizando)]. Se der alguma... desculpa, se der alguma merda, eu fiz tudo que eu podia, com todo o amor, sabe, então já não é minha culpa, eu acho. Entendeu... então, é por isso que eu falo, tenho, sim, a minha consciência tranquila.

É preciso destacar, no entanto, que a apreciação do esforço e do sacrifício, que emerge das entrevistas com as mães em tempo integral, é bastante seletiva e não se aplica, por exemplo, ao caso das mães que têm alguma ocupação no mercado de 
trabalho. "Filhos de mães que trabalham" é a expressão utilizada pelos entrevistados para identificar as crianças e adolescentes que circulam pelo clube sozinhos ou acompanhados por babás ou motoristas da família. Trata-se, para essas mães em tempo integral, de crianças e adolescentes "abandonados" no clube. Entendem que as mães atuantes no mercado de trabalho "terceirizam" os cuidados com os filhos ao deixá-los sob a responsabilidade de babás, empregadas domésticas e motoristas. São mães que, dizem as fofocas, não se aplicam suficientemente no trabalho visto como necessário para a educação das crianças. Como consequência, seus filhos que circulam pelo clube são, em geral, notados como dignos de pena, objeto de preocupação e, não raro, de censura e reprovação.

Verifica-se, então, quer seja no mundo do hipismo, no mundo dos negócios ou no que se acredita ser o mundo da maternidade, que é percebido como sucesso apenas aquilo que pode ser atribuído à dedicação e ao esforço do indivíduo. No entanto, a valorização dessa dedicação e esforço enunciada pelas sócias e sócios entrevistados é, ela própria, articulada a distinções e separaçóes entre o que se considera esforço e dedicação legítimos e o que não pode ser tratado como tal. E o valor das pessoas é estimado em decorrência desses julgamentos. Segue-se, daí, que essa visão de mundo supóe que as diferenças entre as pessoas sejam atribuídas fundamentalmente à sua capacidade de investir no trabalho, mas desde que esse seja um trabalho considerado legítimo.

O caráter regressivo, isto é, as consequências políticas do apego demonstrado por tais grupos a esse modo de organizar o mundo e de classificar as pessoas tornam-se visíveis apenas quando se nota que é utilizado, sem maiores dilemas, para estruturar a percepção dos sócios em relação aos trabalhadores não sócios com quem convivem no interior do clube e no espaço doméstico, o que veremos na próxima seção.

\section{Esforço, merecimento e privilégios de classe}

Aplicada aos funcionários do clube e àqueles que servem às famílias, essa visão de mundo se or- ganiza em dois eixos. Por um lado, os funcionários são "iguais" e, como tal, "dignos de respeito". Por outro lado, são comumente vistos como "uns coitados". Em conjunto, essa dicotomia acaba por criar certa ambivalência, que não deixa de ser percebida por todos os envolvidos.

O direito ao tratamento igualitário e ao respeito é, claro, reivindicado pelos próprios funcionários, como no caso de Isaías. De origem pobre, Isaías chegou aos esportes hípicos por meio de um projeto social. ${ }^{5}$ Começou no salto e hoje integra a equipe brasileira de uma das modalidades hípicas. Quando não está treinando, Isaías ganha a vida como instrutor de equitação na escolinha do clube e em outras hípicas da região. Ele explica que, "por ser um esporte de elite", sempre se dedicou muito, "porque ou eu era bom ou eu não tinha o que tá fazendo no meio do esporte". Na entrevista, Isaías também explica que havia sido ensinado, pela família e pela vida, a não se sentir melhor nem pior do que ninguém. Tudo isso, no entanto, não é suficiente para evitar o peso da hierarquia que organiza as relaçóes sociais no clube.

Eu me sinto [quando monta]... até hoje eu tenho uma sensação muito boa, porque, assim... em momento nenhum eu tiro da cabeça de onde eu sou... não, de onde eu vim, porque até hoje eu ainda sou dessa realidade, da classe baixa... hoje eu tenho uma vida de classe média, graças ao hipismo. Se fosse por outros caminhos, eu náo teria. Mas... quando eu subo no cavalo, eu me sinto igual, quando eu desço do cavalo, eu não me sinto igual a um aluno meu, não me sinto igual a um pai de aluno meu. Quando eu estou em cima do cavalo, eu me sinto igual [frisando] ou até melhor, porque lá em cima eu sou melhor que alguns, então isso me dá o ego de ser... pelo menos lá em cima eu sou melhor que eles.

Do ponto de vista dos sócios, o direito ao respeito é entendido, principalmente, como direito a um tratamento polido, que inclui atenção ao bem-estar da pessoa. Assim, todo tratamento descortês e toda manifestação de "falta de consideração" se torna muito rapidamente assunto da 
fofoca diária e é objeto de intenso escrutínio e reprovação por parte de todos - mães, pais, crianças ou adolescentes.

Como explica Maria (pouco mais de 40 anos, máe de duas meninas, de 14 e 8 anos), "como [em] todo lugar, aqui também tem [quem], porque monta cavalo, porque faz um esporte caro, acha que pode pisar [nos outros]".

E Mônica vai mais longe quando afirma que

[...] aqui no Equestre é muito desrespeito. [...] E aqui não tem "bom dia", "boa tarde" para funcionário e tal. Entáo, é isso que eu falo, vem daí. Eu acho que o problema começa aí, sabe, é o que eu sempre falo para as crianças: tem que ter respeito pelas pessoas, náo é porque o que ela é, entende? Aqui no hipismo, por exemplo, como é que você quer que um tratador seja feliz cuidando de um cavalo de 100 mil reais se ele pega uma marmitex, senta ali no meio daquelas cocheiras, do lado do cavalo, e come ali? Ele fica cuidando do seu cavalo e você chega e nem fala "bom dia" pra ele. Entende o desrespeito de onde vem? [...] Caixas de maçã argentina para os cavalos... Ótimo, se você tem um cavalo, você tem que cuidar mesmo e tal, mas aí o cara chega na casa dele e não tem arroz e feijāo, entende? Entáo é um contraste, né? Então, aqui no Equestre, por exemplo, eu vejo muito [isso].

Quando se trata de episódios envolvendo crianças ou adolescentes, as críticas são dirigidas aos pais, particularmente às mães. Crianças e adolescentes que destratam funcionários sáo vistos como resultado de uma criação que os faria acreditar que "podem tudo". Como explica Eliza, "tem criança que tem três anos e fala assim: [imitando uma voz infantil] 'se você fizer isso, eu te demito!"”.

Além do tratamento cortês, espera-se certo cuidado com as condiçóes de trabalho, como explica Maria.

[Nos campeonatos], o tratador dorme na mesma cocheira, quer dizer, numa cocheira igual à do cavalo.
Pesquisadora: $\mathrm{O}$ tratador dorme lá?

Maria: Dorme, nas provas. Então é alugado um... [chama] quartinho de cela... É uma cocheira a mais onde colocam as coisas, o material e o tratador. Quando chega a prova, [às vezes] chove que é uma desgraça, então a preocupação que ele [o marido] tem é de não deixar faltar, "Tá tudo bem, você precisa de alguma coisa?", "Não, tá tudo bem", "Não, não é o cavalo, é você! Você tá precisando de alguma coisa, como é que tá o seu colchão, você tem cobertor, você trouxe blusa, você trouxe remédio?”. Então é uma preocupação que a gente tem. [...] É difícil, é difícil... Tem pais que têm essa preocupação, mas outros não. Outros acham que um presente no final de ano, uma cesta de Natal, apaga tudo, a malcriação, a falta de educação...

Mesmo os adolescentes demonstram prestar atenção a esse tipo de atitude e a rejeitam, reclamando, geralmente em tom escandalizado, de crianças que, segundo eles, maltratam babás, instrutores, tratadores: "ficam xingando", "dizem 'você não manda em mim!"”, mesmo quando "são pirralhinhos bem pequenininhos".

Bárbara, 14 anos: Um exemplo: o chicote caiu. Ao invés dele chegar pro instrutor e falar assim: "olha, por favor, dá pra você pegar o meu chicote que caiu ali", ele chega [e diz]: "ô, pega o meu chicote que caiu ali, por favor!" [com voz rude]. Não, nem fala "por favor". Só que é, sabe, é muito feio. Você, tipo, você [é] quem tem que respeitar ele. Tem gente que responde para o professor, tem gente que acha legal, eu acho ridículo, porque ele tem é que te ensinar, não [está ali para] você montar nele.

A reprovação ao "desrespeito" é, no entanto, acompanhada por sentimentos de "dó" e "piedade", que denunciam a relação personalista que os patróes estabelecem com os empregados, na qual se considera apenas o indivíduo e suas circunstâncias, ignorando as condiçóes sociais que produzem tais circunstâncias. Assim, os funcionários do clube ou das famílias, embora considerados como "iguais" a 
priori e, por isso, "dignos de respeito", são também "pessoas "simples", "uns coitados".

Em certa ocasião, comentando o comportamento de um dos cuidadores, que mais ao longe se movimentava de um lado para outro, preparando uma longa fila de cavalos para as aulas, Talita, 16 anos, explicou que toda aquela movimentação não significava que ele tinha muita coisa para fazer, mas decorria do fato de ele ser "muito pequeno", numa referência à baixa estatura do funcionário, e "meio retardado", pois "não sabe ler nem escrever". Sem condiçóes de decifrar a lista que definia os cavalos a serem encilhados naquele dia e a ordem em que seriam montados, esse funcionário, explicou ela com uma expressão levemente divertida, "aumenta o seu serviço vinte vezes mais [reforçando] do que seria necessário".

Aliás, importa assinalar que a própria visão de maternidade dedicada, que desvaloriza as "mães que trabalham fora", desvaloriza também, tacitamente, o trabalho das babás, das empregadas domésticas e dos motoristas envolvidos no cuidado com as crianças.

Eliza: E eu, por exemplo, nunca tive babás, sempre fui eu que... [Houve uma moça que ficava meio período] Então, junto comigo... ela me ajudava muito com o [nome do filho], quando ele era pequeno. $\mathrm{O}$ trabalho da criança quando tá andando, de sair andando, correndo, não sei o que... e de ficar dando atenção... nisso ela ajudou muito, brincava com ele e tal. Mas na hora do banho, sempre fui eu que dei, na hora de dar comida, sempre fui eu que dei.

Essa desvalorização está, pelo menos em parte, relacionada com a visão de que se trata aí de pessoas "de pouca educação", sem plenas condições de transmitir os valores que essas famílias consideram ser os mais importantes. Como explica Roberta (43 anos, formada em educação física, mãe de um jovem de 17 anos e de uma menina de 10 anos):

Você vê a moça que trabalha na minha casa... O filho dela... que é uma pessoa... que é empregada doméstica, o filho dela leva... assim... bolinho Pullman, coisas... assim... que são caras, entendeu? "Não quero a metade!", [ele diz] e joga fora... Então, eu acho que tem essa coisa da educação. Então eu acho isso, acho que o Brasil é um povo muito mal educado, não tem educação.

Nessa visão de mundo, as pessoas são consideradas responsáveis por suas próprias circunstâncias, como relata Eliza, num trecho de entrevista particularmente revelador.

E... uma das coisas que eu penso... eu já fiz trabalho voluntário... não vou falar onde foi. Eu... eu... não tenho muita, também, ilusão com pobre. Porque eu acho que as pessoas também são muito responsáveis pelas opções que elas... hummm... tomam, as opçóes que elas acabam escolhendo. Então, eu sofri muito quando eu fiz esse trabalho voluntário, que era só com meninas, meninas... assim... que já foram violentadas, sabe? Meninas que eram...

Pesquisadora: Estupradas?

Eliza: É, é, de verdade mesmo, pelo padrasto. E que, por exemplo, estavam lá, e que...no lugar onde elas estavam... [os funcionários] sabiam dos maus tratos, tudo. E tinha denúncia. Daí a assistente social vai, retira a menina, põe no abrigo, ah... esse tipo de coisa. Mas também tem muita gente ruim. Tem muita criança, sabe, é de índole [enfatizando]. Como tem rico ruim, tem pobre ruim, entendeu? Então... assim... eu falava: "Ah, se eu ganhasse muito dinheiro, ia pegar, ia dar pra uma instituição". Eu acho que... [hoje]... não é o caminho. Eu acho que até eu ia ajudar, mas não dando dinheiro, entendeu? E também acho que as pessoas têm as suas responsabilidades, sim. Eu vejo pela [empregada], minha funcionária... por exemplo, a filha dela. A filha dela tem 26 anos e ela se formou, ela é enfermeira...

Pesquisadora: Ah, ela conseguiu, então?

Eliza: Conseguiu, é. Lógico que teve muita ajuda da gente, né, que a gente tinha uma estrutura boa para ela estar podendo estudar. Só estudou. 
Ela só foi trabalhar depois que se formou. Então, assim, é uma oportunidade... Por exemplo, na família dela, ela é a única diplomada. Então você imagina isso, sabe? Eles nem têm noção do valor de um diploma, viu? Não têm, muita gente não tem: o avô não tem, entendeu? A mãe, sim. A mãe, a [nome da empregada] fica muito feliz por isso. Então, eu acho assim... Mas ela teve as escolhas dela, entendeu? Porque ela podia muito bem não querer. Então, acho assim que... é lógico, não pegar uma criança que nasceu e que é abandonada, jogada na rua... essa, coitada, realmente não tem nem como você falar: "Ah, mas as opçóes que ela teve"... Pô, não teve opção nenhuma aí... Mas, assim, porque a gente fica pensando num mundo melhor, né, viver num mundo melhor, e até que ponto você também é responsável por isso.

Como esses exemplos permitem perceber, a visão que leva à crença de que cada um é responsável por suas próprias circunstâncias faz com que as práticas e os valores esposados por aqueles que são considerados "mais simples" possam ser tomados como indicadores do (menor) valor da pessoa.

Além disso, embora o grupo valorize o sucesso advindo do trabalho duro e do esforço pessoal, as fofocas mostram que nem todo trabalho é valorizado. Da mesma forma como as mães que ocupam posiçóes no mercado de trabalho não merecem respeito por seu esforço, os empregados, mesmo quando exercem trabalhos estafantes ou se esforçam exaustivamente para desempenhar bem o seu papel, não são vistos como necessariamente merecedores de deferência, o que só acontece quando investem no trabalho percebido como mais legítimo.

Vistas como favores, as frestas abertas aos que detêm menores recursos, as chamadas "ajudas", são consideradas, pela maioria dos associados, como oportunidades suficientes para mudança de condição social, sem que se leve em conta as inúmeras outras barreiras que devem ser enfrentadas. Caso o sucesso não se concretize, apesar das "ajudas”, os agraciados tendem a ser responsabilizados individualmente pela própria situação, reforçando a ideia de que se é pobre porque não se soube aproveitar as chances "dadas de presente".
Não se pode perder de vista, portanto, que as demonstrações de "compaixão" são direcionadas aos empregados considerados "dignos" desse sentimento, isto é, os funcionários mais pobres que incorporam um conjunto de valores morais geralmente associados, pelos grupos dominantes, aos grupos dominados. Como argumenta Candace Clark (1997, p. 228),

[...] mesmo quando aqueles que se compadecem não têm a intenção consciente de fazê-lo, compadecer-se pode ter consequências micropolíticas. Ironicamente, permutar compaixão pode, na economia socioemocional, aproximar as pessoas e ao mesmo tempo aprofundar o abismo social entre elas.

Em contrapartida, quando esses grupos não se comportam da maneira esperada pelos grupos dominantes, entrevemos variadas reaçóes de "desprezo", "esse complexo emocional que articula e mantém a hierarquia, o status, a classificação e a respeitabilidade”, como afirma William Ian Miller (1997, p. 217), sublinhando o caráter recorrente dessa situação, na qual "o desprezo ajuda a criar e manter as estruturas que geram a capacidade do desprezo", contribuindo para "acreditar que o estilo específico de desprezo estará intimamente ligado aos arranjos sociais e políticos particulares nos quais ele se dá”.

Ambas as emoções, compaixão e desprezo, servem, portanto, para definir fronteiras entre os grupos sociais; no caso das famílias aqui estudadas, implica um esforço para demarcar sua superioridade.

Embora os associados reconheçam que ocupam uma posição privilegiada na estrutura social brasileira, é importante identificar que é, nas suas interaçóes cotidianas com pares e subalternos, que afirmam essa condição. Decorre daí a relevância de se compreender o repertório avaliativo que mobilizam nesse processo.

\section{Consideraçóes finais}

Muito esforço de pesquisa tem sido dispendido para descrever e medir a desigualdade social brasileira. Neste artigo, procuramos avançar em uma 
proposta analítica assentada sobre o exame das estruturas cognitivas, valores internalizados e repertórios de ação mobilizados por membros dos grupos dominantes nas suas interaçóes cotidianas, para capturar dinâmicas culturais que podem contribuir para explicar sua persistência no tempo.

O recenseamento das percepçóes de indivíduos desses grupos sobre o lugar que ocupam no mundo e sobre aquilo que os mantém nesse lugar revela os contornos da narrativa que mobilizam para explicar o monopólio ou a parte vantajosa que detêm sobre recursos disputados socialmente. Como procuramos mostrar, a situação desses grupos e, em particular, os benefícios a que têm acesso são percebidos, por seus membros, como resultado dos investimentos que fizeram, do sacrifício e dedicação que puderam e podem demonstrar em função de suas qualidades individuais particulares. A dimensão temporal desse esforço, persistentemente sublinhada no discurso dos entrevistados, é apenas mais uma dimensão na qual ideias sobre o investimento pessoal e os sacrifícios realizados são mobilizadas como explicação legítima para a posição que ocupam no mundo.

Observamos, em nosso estudo, que a percepção do seu próprio merecimento orienta a visão que os indivíduos ouvidos na pesquisa têm sobre quem eles são, e apoia a construção de distinções com relação tanto a membros de outros grupos sociais como a membros do seu próprio grupo. $\mathrm{O}$ merecimento é percebido como resultado de um esforço individual, que emana de disposiçóes inatas ou, quando associado a investimentos de pais e mães, emana das qualidades inatas destes. A posição privilegiada não pode, nessa lógica, ser atribuída a configurações coletivas ou a privilégios de classe de nenhum tipo, tampouco se vincula a conhecimentos específicos ou a competências particulares. Para os indivíduos ouvidos na pesquisa, o valor da pessoa parece derivar exclusivamente de suas qualidades morais.

Não é surpresa, portanto, que adultos e adolescentes percebam os funcionários do clube e suas famílias de forma ambivalente: por um lado, são considerados pessoas iguais a todos e, por isso, merecedoras de um tratamento cortês e civil; por outro, no entanto, são dignos de pena. Já que não dispóem de outra chave interpretativa para com- preender suas circunstâncias para além da moralidade, veem a condição dos funcionários como tributária de falhas pessoais, típicas de seres inferiores, incompletos, a quem se destina alternadamente compaixão e desprezo.

Tudo se passa, assim, como se essas famílias, que já se encontram em posiçóes privilegiadas há algumas geraçóes ou que enriqueceram mais recentemente, compartilhassem um conjunto de valores e uma visão de mundo que as protege de reconhecer sua presente situação como efeito de um mecanismo de distribuição de riquezas socialmente engendrado. As crianças e adolescentes, por sua vez, são envolvidos por essa lógica e parecem estar assimilando as visōes de mundo que sustentam agregação e desagregação entre os grupos, que se materializam em valores, escolha de profissões, projetos de futuro, modos de agir segundo a interiorização dos "limites", do que seria ou não possível para cada indivíduo. Essa crença em sua própria superioridade, que lhes permite justificar sua posição privilegiada por suas capacidades e competências pessoais, concebidas como especiais, concretiza-se em alianças, negociaçóes, disputas pelos valores considerados mais legítimos e pode impedir o acesso de membros dos outros grupos aos recursos de poder, sejam materiais ou simbólicos (Elias e Scotson, 2000), contribuindo para a legitimação das desigualdades.

Constrói-se, assim, a invisibilidade dos condicionantes sociais dos próprios investimentos familiares, isto é, do esforço e da dedicação, porque não se reconhece o que o rendimento de tal esforço e dedicação deve aos recursos especiais a que esses indivíduos tiveram acesso simplesmente por nascerem em famílias escolarizadas e estáveis economicamente. Desconhece-se, em particular, o que sua condição presente deve ao usufruto das benesses que as políticas públicas e o arcabouço jurídico nacionais têm garantido aos grupos mais privilegiados como, entre outros, a baixa penalização da transmissão por herança de bens econômicos para as próximas geraçóes e o acesso a setores do sistema de ensino em condiçóes de prepará-los para as longas trajetórias escolares, que, levando a cursos superiores valorizados em universidades prestigiosas, dão acesso a credenciais e redes de interconhecimento que os colocam em posição vantajosa na disputa por postos cobiçados no mercado de trabalho. 
Como resultado, a crença no merecimento individual derivado do esforço sustenta a percepçáo de que aqueles que náo desfrutam de condiçóes objetivas similares poderiam estar na mesma posição, caso se esforçassem mais ou se dedicassem mais. Quando se fala na "falta de opçóes" dos pobres, percebe-se que se referem apenas às situaçóes mais extremas, que consideram raras ou pouco frequentes, já que, a percepção geral é que todos têm, pelo menos, algumas opçóes. Estão criadas, assim, as condições necessárias para que o outro seja percebido como o único responsável por sua situação de vida, podendo despertar apenas dó e piedade, já que a assimetria das posiçóes está plenamente justificada.

São, portanto, individuais as soluçóes que os entrevistados formulam para combater as injustiças e as desigualdades. Acreditam que, se todos "fizessem a sua parte" individualmente, isto é, se agissem com "ética" e "honestidade", "não roubassem", "votassem em bons políticos", criassem seus filhos com uma "boa estrutura", o país já poderia "estar melhor" ou "tudo seria diferente". Parecem, assim, atribuir os problemas brasileiros a desvios de caráter dos indivíduos, tanto dos eleitores como daqueles que ocupam posiçóes de poder político.

A observação das interações no espaço controlado e hierarquizado do clube privado nos permitiu registrar como essa forma de conceber o outro resulta em um padrão de relaçóes marcado pela condescendência, mesmo quando esta é permeada pela civilidade, que assume ali a denominação de "respeito". Percebidos como diferentes, porque não exibem os marcadores do merecimento individual que tanto prezam os mais privilegiados, funcionários do clube a quem são atribuídas as tarefas manuais, como também babás, empregadas domésticas e motoristas particulares podem ser apenas objeto de piedade e caridade, raramente sujeitos de direitos.

A utilização intensa do clube como espaço de sociabilidade das crianças e adolescentes é um dos dispositivos de controle das companhias impostos a eles, que acaba por limitar suas relaçóes, restringindo o convívio com os diferentes, isto é, com indivíduos de outros grupos sociais, sendo possível apenas em situações em que esses indivíduos se encontram submetidos a relaçóes de subordinação. $\mathrm{O}$ clube, como continuação da casa, oferece, assim, o seu próprio reforço aos princípios de socialização prezados pelas famílias, somando-se à segregação urbana e escolar.

Notando a maneira como a desigualdade social contribui para modular a compreensão do "eu" e do "outro", nosso estudo mostra a importância de se atentar para o trabalho de construção de sentido sobre o valor das pessoas (Lamont, 2000a) quando se pretende apreender as dinâmicas sociais que organizam debates sobre políticas, em particular aquelas que, almejando a expansão de direitos para toda a população, supóem o alargamento da definição do grupo que chamamos de "nós".

\section{Notas}

1 Uma exceção é a análise proposta por Graziella M. Silva e Matias López (2015), que explora observaçôes e julgamentos sobre "o povo" ou "os pobres" surgidas em entrevistas com grupos pertencentes às elites.

2 Ver Andreas Wimmer (2008), que faz revisão dos usos da noção de fronteira na formulação pioneira de Barth (1969).

3 A parte mais intensa da pesquisa ocorreu do segundo semestre de 2010 até o final de 2011. Consistiu em visitas ao clube, em geral três vezes por semana, com duração de três a quatro horas, rotina interrompida nos meses de dezembro e janeiro. Nessas visitas, a maior parte do tempo era despendida na observação das aulas de hipismo e na interação com mães, pais, crianças e adolescentes que por ali circulavam. Foram também, observados campeonatos ocorridos em finais de semana nas dependências do clube. $\mathrm{O}$ número de crianças e jovens praticantes de hipismo variou durante o período, ficando em torno de 78. Desses, apenas sete não eram sócios. Além disso, foram realizadas 29 entrevistas formais com mães, um pai, instrutores e instrutoras, babás e motoristas particulares. Nomes próprios foram modificados, conforme acertado com os entrevistados e com os membros da administração do clube que autorizaram a realização da pesquisa.

4 Trata-se de um padrão evidente em diferentes regióes do país. A esse respeito, ver Cattani e Kieling (2007), entre outros.

5 Isaías repete, aqui, uma trajetória registrada por Adelman e Costa (2017) em seu estudo sobre a cultura dos "empregados de estábulo", que oferece ampla visão sobre o mundo das práticas equestres em meios mais elitizados e entre os grupos populares. 


\section{BIBLIOGRAFIA}

ADELMAN, Miriam \& MORAES, Fernanda Azeredo de. (2008), "Tomando as rédeas: um estudo etnográfico da participação feminina e das relaçóes de gênero no turfe brasileiro”. Revista Esporte e Sociedade, 3 (9): 1-29.

ADELMAN, Miriam \& COSTA, Tiemi K. Lobato. (2017), "From hípica to cabanha: Brazilian stable hands in different cultures and contexts", in M. Adelman e K. Thompson, Equestrian cultures in global and local contexts, Suíça, Springer.

ALMEIDA, Ana Maria F. et al. (2010), "Fronteiras Sociais no Brasil", in M. Saint Martin e M.D. Gheorghiu (dirs.), Education et frontières sociales: un grand bricolage. Coordenado por Bénédicte Montvalon, Paris, Michalon.

ALMEIDA, Ana Maria F.; MOSCHKOVICH, Marília \& POLAZ, Karen. (2012), "Pesquisando os grupos dominantes: notas de pesquisa sobre acesso às informaçóes". Revista Pós Ciências Sociais, 9 (17): 1-14.

BALTZELL, Edward Digby. (1964), The protestant establishment. Nova York, Random House.

BARBOSA, Lívia. (1996), "Meritocracia à brasileira: o que é desempenho no Brasil?”. Revista do Serviço Público, 120 (3): 58-102.

BARROS, Ricardo Paes; HENRIQUES, Ricardo \& MENDONÇA, Rosana. (2000), "Desigualdade e pobreza no Brasil: retrato de uma estabilidade inaceitável”. RBCS - Revista Brasileira de Ciências Sociais, 15 (42): 123-142.

BARTH, Fredrik. (1969), Ethnic groups and boundaries: the social organization of culture difference. Boston, Little, Brown, and Co.

BLOFIELD, Merike (ed.). (2011), The great gap: inequality and the politics of redistribution in Latin America. Pennsylvania, The Pennsylvania University Press.

BOND, Mathew. (2012), “The bases of elite social behavior: patterns of club affiliation among members of the House of Lords". Sociology, 46 (4): 613-632

BOURDIEU, Pierre. (1972), Esquisse d'une théorie de la pratique précédé de trois études d'ethnologie kabyle. Genève, Droz.

BRUBAKER, Rogers; LOVEMAN, Mara \& STA-
MATOV, Peter. (2004). "Ethnicity as cognition". Theory and Society, 33 (1): 31-64.

CALDEIRA, Teresa Pires do Rio. (2000), Cidade de muros: crime, segregação e cidadania em São Paulo. São Paulo, Editora 34.

CARVALHO, José Murilo de. ([1980] 2012). A construçâo da ordem: a elite política imperial [seguido de] Teatro de sombras: a política imperial. Rio de Janeiro, Civilização Brasileira.

CATTANI, Antonio David \& KIELING, Francisco dos Santos. (2007), "A escolarização das classes abastadas". Sociologias, 18: 170-187.

CLARK, Candace. (1997), Misery and company: Sympathy in everyday life. Chicago/Londres, The University of Chicago Press.

CHARLES, Maria. (2008). "Culture and inequality: identity, ideology, and difference in 'postascriptive society". The Annals of the American Academy of Political and Social Science, 619: 41-58.

DOMHOFF, William G. (1971), The higher circles. Nova York, Random House.

DOMHOFF, William G. (1975), "Social clubs, policy planning groups and corporations: a network study of ruling-class cohesiveness". Critical Sociology, 5 (3): 171-184.

DOUGLAS, Mary \& ISHERWOOD, Baron. (2004), O mundo dos bens: para uma antropologia do consumo. Rio de Janeiro, Editora da UFRJ.

ELIAS, Norbert \& SCOTSON, John L. (2000), Os estabelecidos e os outsiders: sociologia das relaçôes de poder a partir de uma pequena comunidade. Rio de Janeiro, Jorge Zahar.

FLETCHER, Thomas \& DASHPER, Katherine. (2013), “'Bring on the dancing horses!': ambivalence and class obsession within British Media reports of the dressage at London 2012". Sociological Research Online. Disponível em http://www.socresonline.org.uk/18/2/17.html, consultado em 13/1/2018.

FONSECA, Claudia. (2000), Família, fofoca e honra. Porto Alegre, Editora da UFRGS.

FREYRE, Gilberto. ([1933] 1995), Casa-grande \& senzala. Rio de Janeiro, Record.

FREYRE, Gilberto. ([1936] 2003), Sobrados e mucambos: decadência do patriarcado rural e desenvolvimento do urbano. Sáo Paulo, Global. 
FRIEDMAN, Hilary Levey. (2013), Playing to win: raising children in a competitive culture. Berkeley/Los Angeles, University of California Press.

JEROLMACK, Colin \& KHAN, Shamus. (2014). "Talk is cheap: ethnography and the attitudinal fallacy”. Sociological Methods \& Research, 43 (2): 178-209.

LACY, Karin R. (2007), Blue-chip black: race, class, and status in the new black middle class. Berkeley/ Los Angeles, University of California Press.

LAMONT, Michèle. (1992), Money, moral and manners: the culture of the French and the American upper-middle class. Chicago, University of Chicago Press.

LAMONT, Michèle. (2000a), "Meaning-making in cultural sociology: broadening our agenda". Contemporary Sociology, 29 (4): 602-207.

LAMONT, Michèle. (2000b), The dignity of working man: morality and the boundaries of race, class, and immigration. Cambridge, Harvard University Press.

LAMONT, Michèle \& MOLNÁR, Virág. (2002), "The study of boundaries in the social sciences”. Annual Review of Sociology, 28: 167-195.

LANGONI, Carlos. (1973), Distribuição de renda e desenvolvimento econômico do Brasil. Rio de Janeiro, Expressão e Cultura.

LAREAU, Annette. (2012), Unequal childhoods: class, race and family life. Berkeley, University of California Press.

LIZARDO, Omar. (2006), "How cultural tastes shape personal networks". American Sociological Review, 71 (5): 778-807.

MEDEIROS, Marcelo; GALVÃO, Juliana de Castro \& NAZARENO, Luisa. (2015), "A composição da desigualdade no Brasil entre 2006 e 2012: resultados adicionais". Texto para Discussão, n. 2147, Ipea.

MEDEIROS, Marcelo \& SOUZA, Pedro H. G. F. (2016), "A estabilidade da desigualdade no Brasil entre 2006 e 2012: resultados adicionais”. Texto para Discussão, n. 2170, Ipea.

MELO, Victor Andrade de. (1998), "Possíveis representaçóes sobre o turfe na sociedade carioca do século XIX”. Lecturas: Educación Física y Deportes, Buenos Aires. Disponível em: http:// www.efdeportes.com/efd9/turf91p.htm, consultado em 13/1/2018.

MILLER, William Ian. (1997), The anatomy of disgust. Cambridge, Harvard University Press.

NERI, Marcelo. (2011), Desigualdade de renda na década. Rio de Janeiro, FGV/CPS.

OSTRANDER, Susan A. (1984), Women of the upper class. Philadelphia, Temple University Press.

PACHUCKI, Mark A. (2007), "Boundary processes: recent theoretical developments and new contributions". Poetics, 35 (6): 331-351.

PINÇON, Michel \& PINÇON-CHARLOT, Monique. (1997), Voyage en grande bourgeoisie. Paris, PUF.

PINÇON, Michel \& PINÇON-CHARLOT, Monique. (2007), Les ghettos du Gotha: comment la bourgeoisie defend ses espaces. Paris, Seuil.

REIS, Elisa. (2000), "Percepçóes da elite sobre pobreza e desigualdade". RBCS - Revista Brasileira de Ciências Sociais, 15 (2): 44-152.

REIS, Elisa. (2004), "A desigualdade na visão das elites e do povo brasileiro", in M. C. Scalon, (ed.), Imagens da desigualdade, Belo Horizonte/ Rio de Janeiro, Editora da UFMG.

REIS, Elisa. (2005), "Perceptions of poverty and inequality among Brazilian elites", in E. Reis e M. Moore (eds.), Elite perceptions of poverty and inequality, Londres, Zed Books.

REIS, Elisa. (2011), "Elite perceptions of poverty and inequality in Brazil", in M. Blofield (ed.), The great gap: inequality and the politics of redistribution in Latin America, Pennsylvania, The Pennsylvania University Press.

REIS, Elisa \& MOORE, Mick. (2005), Elite perceptions of poverty and inequality. Londres, Zed Books.

SAINT MARTIN, Monique \& GHEORGHIU, Mihaï-Dinu (Dirs.). (2010), Education et frontières sociales un grand bricolage. Coordenado por Bénédicte Montvalon. Paris, Michalon

SCALON, Celi. (2007), "Justiça como igualdade? A percepção da elite e do povo brasileiro". Sociologias, 9 (18): 126-149.

SILVA, Graziella M. \& LÓPEZ, Matias. (2015), "Brazilian people in the eyes of the elites: repertoires and symbolic boundaries of inequalities". Sociologia \& Antropologia, 5 (1): 157-182. 
SOARES, Sergei Soares Dillon. (2010), “O ritmo na queda da desigualdade no Brasil é aceitável?”. Revista de Economia Politica, 30 (3): 364380.

SOUZA, Jessé. (2006). A construção social da subcidadania: para uma sociologia política da modernidade periférica. Belo Horizonte/Rio de Janeiro, Editora da UFMG/Iuperj.

SWANSON, Lisa. (2009), "Complicating the soccer mom: the cultural politics of forming class-based identity, distinction, and necessity". Research Quarterly for Exercise and Sport, 80 (2): 345-354.

TILLY, Charles. (2006), Identities, boundaries and social ties. Londres, Routledge.

TOLIPAN, Ricardo \& TINELLI, Arthur Carlos. (1973), A controvérsia sobre a distribuição de renda no Brasil. Rio de Janeiro, Zahar.

VINCENT, Carol \& BALL, Stephen J. (2007), "'Making up' the middle-class child: families, activities and class dispositions". Sociology, 41 (6): 1061-1077.

WEBER, Max. (1999), Economia e sociedade. Brasília, Editora da UnB.

WILLIAMS, Christine L. (2006), Inside toyland. Berkeley/Los Angeles, University of California Press.

WIMMER, Andreas. (2008), “The making and unmaking of ethnic boundaries: a multilevel process theory". American Journal of Sociology, 113 (4): 970-1022. 


\section{FRONTEIRAS SOCIAIS E SIMBÓLICAS EM UM CLUBE DE ELITE}

\section{Ana Maria Fonseca de Almeida e Karen Teresa Marcolino Polaz}

Palavras-chave: Desigualdades sociais; Fronteiras sociais; Fronteiras simbólicas; Elites; Brasil.

Como os membros dos grupos privilegiados percebem a si mesmos? Que grupos consideram como "os outros" e em função de que aspectos, características e dimensóes? Que percepçóes sobre si - e sobre o que os diferencia dos outros - transmitem aos seus filhos? Apoiando-se em entrevistas e observaçôes realizadas em um clube privado, socialmente seletivo, localizado em uma cidade do interior paulista, ao longo de dezoito meses, este artigo (i) descreve o constante e árduo trabalho de construção de fronteiras sociais e simbólicas em que se engajam os indivíduos para definir e negociar diferenças com relação tanto a membros de outras fraçóes dos grupos privilegiados, quanto a membros de grupos menos privilegiados; (ii) identifica elementos do sistema de crenças que dá sentido a esse trabalho de construçáo de fronteiras, apontando, em especial, a centralidade das fronteiras morais; e (iii) documenta processos pelos quais crianças e adolescentes se integram a ele. Ao revelar o modo como tais crenças são mobilizadas nas interaçóes cotidianas e transmitidas para as novas geraçóes, o artigo oferece uma contribuição particular para os estudos sobre a desigualdade social brasileira, identificando o reforço dado pelos indivíduos às hierarquias sociais inscritas nas instituiçóes.

\section{SOCIAL AND SYMBOLIC BOUNDARIES IN AN ELITE SOCIAL CLUB}

\section{Ana Maria Fonseca de Almeida e Karen Teresa Marcolino Polaz}

Keywords: Social inequalities; Social boundaries; Symbolic boundaries; Elites; Brazil.

How do members of the privileged groups perceive themselves? Which groups do they consider as "the others"? Which aspects, characteristics, and dimensions of these groups do they mobilize in order to make these distinctions? Which perceptions about themselves and about what distinguishes them from others do they transmit to their children? Drawing data from an ethnography of an elite social club located in a city in the state of Sáo Paulo, the article (i) describes the social and symbolic boundary work in which members of certain fractions of the upper classes engage in order to define and negotiate differences from other fractions and from members of other social groups; (ii) identifies elements of the belief system that gives meaning to this work, showing the centrality of the moral boundaries, and (iii) documents processes by which children and adolescents integrate with it. By revealing how beliefs are mobilized in everyday interactions and transmitted to the new generations, the article offers a contribution to the studies on Brazilian social inequality, acknowledging the reinforcement that individuals give to the social hierarchies inscribed in institutions.

\section{FRONTIÈRES SOCIALES ET SYMBOLIQUES DANS UN CLUB RÉSERVÉ À L'ÉLITE}

Ana Maria Fonseca de Almeida et Karen Teresa Marcolino Polaz

Mots-clés: inégalités sociales; frontières sociales; frontières symboliques; élites; Brésil.

Comment les membres des groupes privilégiés se perçoivent-ils ? Quels groupes considèrent-ils comme « les autres » et en fonction de quels aspects, caractéristiques et dimensions ? Quelles perceptions sur eux-mêmes - et sur ce qui les différencie des autres - transmettent-ils à leurs enfants ? À partir d'entretiens et d'observations menées pendant dix-huit mois dans un club privé, socialement sélectif, situé dans une ville de l'état de São Paulo, cet article se propose de : (i) décrire le travail constant et ardu de construction de frontières sociales et symboliques des individus pour définir et négocier des différences par rapport à des membres d'autres groupes de même classe sociale et à des membres de groupes moins privilégiés ; (ii) identifier des éléments du système de croyances qui donne un sens à ce travail de construction de frontières, avec l'accent sur les frontières morales ; et (iii) souligner les processus d'intégration des enfants et des adolescents. En montrant comment ces croyances sont mobilisées dans les interactions quotidiennes et transmises aux nouvelles générations, ce travail contribue aux études sur l'inégalité sociale brésilienne. Il identifie le renforcement par les individus des hiérarchies sociales inscrites dans les institutions. 